\title{
An Analysis of Translation Errors: A Case Study of Vietnamese EFL Students
}

\author{
Phạm Thị Kim Cúc ${ }^{1}$ \\ ${ }^{1}$ Department of Foreign Languages, Hung Vuong University, Phu Tho Province, Vietnam \\ Correspondence: Phạm Thị Kim Cúc, Department of Foreign Languages, Hung Vuong University, Phu Tho \\ Province, Vietnam. Tel: 84-976-715-138. E-mail: cucsuzan@gmail.com
}

Received: September 7, 2017 Accepted: September 23, 2017 Online Published: October 25, 2017

doi:10.5539/ijel.v8n1p22 URL: https://doi.org/10.5539/ijel.v8n1p22

\begin{abstract}
The study aimed to analyze the translation errors committed by Vietnamese EFL students, and identify the source of errors, then inform some implications of pedagogy to improve the translation ability of the students. To this end, 36 Vietnamese students, who at the time of the study were studying English as their major, were subjected to a Vietnamese-English translation test. Translation errors were analyzed using a threefold perspective proposed by Popescu (2012) including linguistic errors, comprehension errors, and translation errors. Findings showed that translation errors and linguistic errors are the most common errors, of which errors related to lexical choice, syntax and collocations are the most frequently committed by the students. The source of the errors could be attributed to inter-lingual, intra-lingual interference or errors can be the integration of the source. Results were discussed and implications for the improvements of translation ability and recommendations for future research were presented.
\end{abstract}

Keywords: translation errors, linguistic errors, comprehension errors, translation errors, source of translation errors

\section{Introduction}

The tendency of development of the world in the 21 st century now is based on the integration and globalization. It is a common knowledge that one country cannot be separated from others in the world community. In other words, people depend on each other for the survival, for the existence, and for the development of their own. The need for communication and information exchange among countries and people is more and more increasing. The professional translators and interpreters will be the connectors serving for that need, enhancing the fruit of the activities people do. As Newmark (2003, p. 55) claims, there will be "no global communication without translation".

Translation is not an easy work to do as it is not merely the substitution of words in one language by another language, but the transfer of meaning and sense that the author wants to convey in the most natural way. It, therefore, requires the training of prospective translators be done carefully in order to produce efficient translators.

In the language teaching and learning process, especially the teaching and learning of translation, errors play a crucial role as they 'form part of the student's learning experience, suggesting that they are actively trying out and experimenting with linguistic structures in the foreign language" (Dodds, 1999, p. 58). According to Waddington (2001), error analysis has been an effective tool to assess the translations performed by students. The more errors the students commit in translation, the worse their translation product is (Na Pham, 2005). Identifying the errors committed by the translation learners is very important since errors reflect the quality of a translation and they tell us something about the translation training process (Seguinot, 1990).

In an attempt to open the "windows" to the reality of the translation ability of the students in Vietnamese EFL context, the purpose of the study is to analyze the translation errors committed by Vietnamese students who study English as a major and become translators in the future. Meanwhile, the specific objectives of this study were to 1) analyze the errors committed by students in translation, 2) identify source of errors, and 3) inform some pedagogical implications basing on the identification of errors and their source. 


\section{Theoretical Background}

\subsection{Errors}

The first issue discussed here is what is meant by the term "error". The term "error" usually means that something is wrong. Lennon (1991, p. 182) considers an error as "a linguistic form or combination of forms which, in the same context and under similar conditions of production, would, in all likelihood, not be produced by the speakers' native speaker counterparts".

When trying to look for the concept of the term "error", the two terms, which may easily cause confusion: "error" and "mistake", should be differentiated. Although many people use both terms interchangeably, there is a distinction between the two terms "error" and "mistake". Goff-Kfouri (2004) distinguishes the terms "error" and "mistake" when claiming that: "scientifically speaking, a mistake is generally considered as a fault in performance; it does not occur systematically. An error reflects a gap in student's knowledge and is systematic".

\subsection{Translation Errors}

In the translation field, Neubert \& Shreve (1995) describe a translation error as something that is very complicated and difficult to define and identify. Viewed from the standpoint of equivalence, translation errors can be considered as non-equivalence between source text and target text, or non-adequacy of the target text (Koller, 1979, p. 216, cited in Dewi, 2015). Pym (1992, p. 281) considers errors in translation as a manifestation of a defect in any factors entering into the skills in translation. Hatim \& Mason (1997, p. 203) define translation errors as (1) significant (unmotivated) mismatches of denotational meaning between source and target text (subdivided into omissions, additions and substitutions); and (2) breaches of the target-language system (e.g. orthography, grammar).

Viewed from a functionalistic approach, Seguinot (1990, p. 172) defines translation errors as "an offence against: (1) the function of the translation, (2) the coherence of the text, (3) the text type or text form, (4) linguistic conventions, (5) culture- and situation-specific conventions and conditions, (6) the language system". The "skopos theory" views a translation error "as a failure to carry out the instructions implied in the translation brief and as an inadequate solution to a translation problem" and how much the target text function meets the expectations of the receivers (Nord, 2009, p. 190).

As discussed previously, translations errors are defined differently depending on translation theories and norms (Hansen, 2010). Based on the projects of this study, the concept of translation errors adopted in this study is stated by ATA Framework. According to ATA, translation errors are negative impact(s) on the understanding or use of a target text.

\subsection{Translation Error Analysis}

Until now, there are still no universal translation error categories. The classification of translation errors seems hard to obtain because there are different translation theories, then different definitions of translation errors leading to no universally accepted translation error classifications. Furthermore, different translation language pairs, for instance, Vietnamese and English, or Arabic English, could result in different types of errors (Dewi, 2015). In translation error classification, however, Melis \& Albir (2001, p. 208) suggest that the main questions that need to be considered are the following:

(1) The difference between errors relating to the source text (opposite sense, wrong sense, nonsense, addition and suppression) and errors relating to the target text (spelling, vocabulary, syntax, coherence and cohesion);

(2) The difference between functional errors and absolute errors;

(3) The difference in individual translators between systematic errors (recurrent) and random errors (isolated); and

(4) The difference between errors in the product and errors in the process.

Benhaddou (1991) distinguishes two types of errors: Covertly erroneous errors (dimensional errors): those errors which result from a mismatch along the situational dimensions; and Overtly erroneous errors (non-dimensional errors): those occur at the level of denotative meaning or a breach of the target language system.

Pym (1992) distinguishes between binary errors and non-binary errors. "A binary error opposes a wrong answer to the right answer", so the question of "right" or "wrong" is the main focus for this type of errors (1992, p. 282). By binary errors, Pym means language errors. "Non-binary errors" means the translation errors, which "requires that the target text actually selected be opposed to at least one further target text, which could also 
have been selected, and then to possible wrong answer" (1992, p. 282).

Translation errors, according to Nord (1997), can be classified into four categories: pragmatic, cultural, linguistic, and text-specific. Pragmatic translation errors are the ones that come from the problems of how to deal with pragmatic ambiguities hidden in the source text. Cultural translation errors occur when there is "an inadequate decision" in adapting the source text to the target one in terms of culture (Nord, 1997, p. 75). Linguistic translation errors are the failure in using target language structures to transfer the meaning and sense of the source text. And finally, text-specific translation errors can be traced from the suitability of the translation to the target readers (Nord, 1997).

Waddington (2001) gives a list of translation errors a translator may commit (Method A):

(1) Inappropriate renderings, which affect the understanding of the source text.

(2) Inappropriate renderings, which affect expression in the target language.

(3) Inadequate renderings, which affect the transmission of either the main function or secondary function of the source text.

In order to serve the purpose of the study, the taxonomy for translation error analysis used by Pospescu (2012) was utilized in the present study. The classification of translation errors inspects errors from three dimensions of errors (linguistic errors, comprehension errors, and translation errors) and subtypes within each dimension. Linguistic errors include morphological, syntactic and collocational errors, comprehension errors consist of misunderstanding of lexis or syntax, and translation errors involve errors related to distorted meaning, additions, omissions, and inaccurate renditions of lexical items.

\section{Methodology}

\subsection{Research Design}

Qualitative approach as suggested by Gass \& Selinker (2008) was used in the study. The process included: collection of data, identification and classification of errors, quantification of errors, error source analysis and error remediation. Frequency counts and percentage were utilized to validate the data of translation errors committed.

\subsection{Participants}

The population of the study was the group of 36 fourth year English major linguistic students, Department of Foreign Languages, Hung Vuong University, Vietnam.

At the time of the study, participants were studying "Translation practice 3" subject. Under the umbrella of this subject, students practiced translating texts at upper-immediate level focusing on such topics as agriculture, economy, politics, education, population and urban planning, etc.

\subsection{Instrumentation}

In order to serve the purpose of the study, participants were asked to translate a text from Vietnamese into English. It was about 300 words, which is adapted from part of an article on electronic commerce for general audience. It was written by an expert, but not for other experts in that field, but commercial in the broadest sense (http://englishpro.edu.vn/luyen-dich/linh-vuc-kinh-te/516-quan-he-giua-nha-san-xuat-kinh-doanh-va-nguoi-tieudung-qua-mang-thuong-mai-dien-tu.html).

The validation for the translation test went through the two steps following Suskie's (1996) guidelines, namely "Informal pilots" and "Accompanied interviewing". After the test was piloted, the final form of the test was produced and administered to the participants.

\subsection{Data Collection}

The participants were first informed about the purpose of the test and advised to try their best to complete the test. Although the time allowance was set at 45 minutes, but more time could be given to the participants if needed in order that students would complete the whole text translation.

\subsection{Data Analysis}

The translation error analysis was done by a group of three translation teachers. They were all experienced in the field of translation teaching. The process of data analysis was as follows:

A teacher among the group examined the translations of the participants. She identified the translation errors by using the Guide Sheet for Translation Error Analysis. After that, the researcher and the other teacher-evaluator rechecked the translation error identifications to ensure that they were appropriate. After that, the researcher 
herself classified the translation errors.

\section{Results and Discussion}

\subsection{Translation Errors Committed}

As previously mentioned, the data were collected by manually identifying and then they were computerized for frequency and percentage. The following table presents the error types and the occurrences of the types.

Table 1. Frequencies and percentage of students' translation errors

\begin{tabular}{lll}
\hline Types of Errors & Frequencies & Percentage (\%) \\
\hline Linguistic Errors & $\mathbf{2 5 7}$ & $\mathbf{4 4 . 0 8}$ \\
Morphological & 56 & 9.61 \\
Syntactic & 103 & 17.67 \\
Collocational & 98 & 16.81 \\
Comprehension Errors & $\mathbf{4 4}$ & $\mathbf{7 . 5 3}$ \\
Misunderstanding of the lexis & 19 & 3.26 \\
Misunderstanding of the syntax & 25 & 4.29 \\
Translation Errors & $\mathbf{2 8 2}$ & $\mathbf{4 8 . 3 7}$ \\
Distorted meaning & 76 & 13.04 \\
Additions & 10 & 1.72 \\
Omissions & 13 & 2.23 \\
Inaccurate renditions of lexical items & 183 & 31.39 \\
Total errors & $\mathbf{5 8 3}$ & $\mathbf{1 0 0}$ \\
\hline
\end{tabular}

As seen in Table 1, all types of errors occur, namely: linguistic, comprehension, and translation in which translation errors and linguistic errors account for most of the errors committed by the students with the frequencies of 282 errors (48.37\%) and 257 errors (44.04\%), respectively. Within the subtypes of errors, the most common errors committed by the students are inaccurate renditions of lexical items, i.e., word choice in translation (183 errors, equals to $31.39 \%$ ), syntactic errors (103 errors, or 17.67\%), and collocational errors (98 errors, or $16.81 \%$ ). From the data, it is highly recommended that the vocabulary and syntactic improvements should be given attention in order to facilitate the translation performances. The findings support the study by Hang Nguyen \& Hang Trieu (2015) as it claims that errors relating to lexical choice were the most common. Likewise, the present study supports study results by Popescu (2013) in which collocational errors and inaccurate rendition of lexical items errors are among errors that occur the most frequent in the students' translations.

Following are some examples of translation errors committed by students for each type.

(1) Morphological: ..to choose the items with reasonable price and useful information-s. (Addition of plural marker)

(2) Morphological: Electronic commerce bring(s) many benefits for not only enterprises but customers. (Subject/verb agreement)

(3) Syntactic: ... to choose the items with price reasonable (reasonable price) and necessary information. (Wrong position of adjective in a noun phrase)

(4) Syntactic: In Vietnam, the enterprises succeeded in electronic commerce are thoses specializing in service product high technology (high technology service product) or import-export. (Misordering)

(5) Syntactic: these are one of the modes operation simplest (the simplest operation modes) of commerce electronic (electronic commerce). (Misordering)

(6) Syntactic: Customers do not need to walk on the street to find the products and waste of time and energy ... (Nonparallel combination)

(7) Collocational: The sublimity is expressed in its potential as electronic commerce is the key to go (redundant) to the success of enterprises in the future.

(8) Collocational: If enterprises do not use electronic commerce, they cannot use (take) the advantages of electronic commerce which are greater than those of other business forms.

(9) Misunderstanding of the lexis: 
Source text: Thuơng mại điện tử vìa cao siêu nhung lại rất bình thuờng.

Translated text: Electronic commerce is both supermodern (sublime) and simple.

(10) Misunderstanding of the syntax: Electronic commerce does not only bring many benefits for enterprises but also customers. (In this case, the structure "not only ... but also" should be used to combine "enterprises" and customers' as the electronic commerce brings benefits for both of them).

(11) Distorted meaning:

Source text: Nếu không sủ dụng thuơng mại điện tử thì các doanh nghiệp không tận dụng được nhũng uu điểm hơn hẳn các hình thức kinh doanh khác.

Translated text: Enterprises are unable to take advantages of their strengths compared to other business forms without electronic commerce.

The distortion error comes from the inability to render the intended meaning of the phrase "tận dụng được những ưu điểm" (take full advantages) in the source text. In this case, the intended meaning is the advantage of electronic commerce, but the translation of the student impede the reader's comprehension into "take full advantages of the enterprises".

(12) Additions: Translated text: ... Instead of wasting time and energy wandering on streets to look for the products like the traditional way, customers now just sit on the chairs and "move the mouse". (The meaning of "like the traditional way" does not appear in the source text)

(13) Omissions: then choose the items with $\sqrt{ }$ (reasonable price and) necessary information.

(14) Inaccurate renditions of lexical items:

Source text: Thuoong mại điện tử không chỉ đem lại nhiều lọi ích cho các doanh nghiệp mà còn với cả khách hàng.

Translated text 1: Electronic commerce brings many profits for not only enterprises but also customers.

Translated text 2: Electronic commerce brings many advantages for not only enterprises but also customers.

Possible translation: Electronic commerce brings many benefits for not only enterprises but also customers.

(15) Inaccurate renditions of lexical items:

Source text: Thuong mại điện tủ̉ không chỉ đem lại nhiều lợi ích cho các doanh nghiệp mà còn với cả khách hàng.

Translated text 1: Electronic trade brings benefits for not only enterprises but customers as well.

Translated text 2: Electronic business brings benefits for not only enterprises but also customers.

Possible translation: Electronic commerce brings benefits for not only enterprises but also customers.

(16) Inaccurate renditions of lexical items:

Source text: Bình thường ở chỗ: các doanh nghiệp Việt Nam, nhất là tại Hà Nội và thành phố Hồ Chí Minh, tì lâu đã sử dụng các phuoơng tiện nhu máy điện thoại, fax, email .. trong giao dịch thưong mại.

Translated text 1: It is simple because Vietnamese enterprises, especially those in Hanoi and Hochiminh city, have been using such means (of communication) as telephones, faxes, emails, .. in trade exchange for a long time.

Translated text 2: It is simple (because) Vietnamese enterprises, especially (those) in Hanoi and Hochiminh city, used (have been using) such means of communication as telephones, faxes, emails, .. in transaction of trade for a long time.

Possible Translation: It is simple because enterprises in Vietnam, especially those in Hanoi and Hochiminh city, have been using such means of communication as telephones, faxes, emails, .. in business transaction for a long time.

\subsection{Source of Errors}

In an attempt to investigate the causes of the translation errors, the researcher integrates the ideas of the teachers of translation and English linguistic students in informal interviews and observations of the researcher herself about problems in her translation classes. They reveal the source of translation errors of the students, which can be attributed to both inter-lingual and intra-lingual interference (James, 1988). 
Mother tongue interference can be traced in some cases when students employ a word-by-word translation for English collocations or construct English word group or sentences basing on the direct translation of Vietnamese into English (James, 1988). Example 7 presented in this study demonstrates the direct translation of Vietnamese collocation into English collocation, as the source text says "chia khoá để đi tới thành công." then the translated text is "the key to go to the success..". In this case, there is no need to add the word "to go" (để đi tới) in English as the collocation "the key of the success" can transfer the meaning of the collocation. As the students have been habituated to the structure in the Vietnamese language to express the idea, they unconsciously apply the same structure in the target language when performing the translation task.

The interference of Vietnamese language was also found in syntactic errors. Word order errors as presented in Example 3, Example 4, Example 5 are traced due to the difference between Vietnamese language and English language. In Vietnamese, an adjective comes after a noun which is opposite in English structure of adjective plus noun to form a noun phrase, as shown in "một (a) cô gái (girl) đẹp (beautiful)". In contrast, the English noun phrase should be "a beautiful girl" as the rule requires a adjective must precede the noun it modifies. For this source, students commit the error of noun phrase construction when the adjective is put in the wrong position. Furthermore, it is the word-by-word translation from Vietnamese into English that causes the errors.

Likewise, the interference of Vietnamese language can be found as the source of some other linguistic errors. In the following example, students directly translate the word "dường như" which is equivalent to "seem" in this case, ignoring that it needs a subject for the verb to form a clause in the English language. The students tend to construct the English word groups and sentences basing on their habit in using mother tongue language.

(17) Source text: Và dường như doanh nghiệp nào sớm áp dụng thương mại điện tử thì sớm thành công.

Translated text: $\underline{\sqrt{ }(I t)}$ seem $(s)$ that the sooner the enterprises apply electronic commerce, the greater success they get.

Moreover, the reason why the passive voice is not used when it should be comes from the thinking in Vietnamese language as in the source text the author uses the active voice, but in the target language passive voice sounds idiomatic.

(18) Translated text: The sublimity express (is expressed) in its potential.

The rule of adding "s" to form plural in English is frequently ignored by Vietnamese students as that rule does not exist in Vietnamese language as follows.

(19) Translated text: It is one of the simplest transaction mode-s of electronic commerce.

The intra-lingual interference, "the deviate form of language caused by conflicting information of the target language" (Kaweera, 2013, p. 6), was also found as a major cause of students' errors. In the case of this study, students might mistakenly assume the rules in English from their known information (Example 20: students know the rule of using past participle to form passive voice but use the wrong past participle form of the verb "show"), wrongly understand the concept of a particular rule (Example 21: wrong use of part of speech of the word), apply the rule incompletely (Example 22: students are unable to produce an acceptable utterance in English), or ignore the exception of the rule (overgeneralization) (Example 23) (James, 1988; Kaweera, 2013). These lead to the linguistic incompetence of the students. Following examples illustrate the point.

(20) Its sublimity is showned in its potential as electronic commerce is the key to (reach) the success of enterprises in the future.

(21) It is the key to help enterprises become success (successful) in the future.

(22) Electronic commerce not only brings many benefits for enterprises but also does it bring benefit for customers.

(23) The sublimity is expressed in its potential as this is the key to the enterprises's success in the future.

Though the study clarifies the source of errors as inter-lingual and intra-lingual as suggested by James (1988), it is noted that in many cases they don't reflect an isolated factor as stated by Kaweera (2013, p. 15) that "errors may be caused differently and be complex in which it can be overlapped and sometimes doesn't belong to a clear-cut category". There is no clear distinction between these sources. Instead, errors can be the integration of the sources.

\section{Conclusions}

\subsection{Main Findings}

Translation errors were analyzed on three dimensions: linguistic errors, comprehension errors, and translation 
errors. Results showed that, among the three dimensions, errors related to linguistic and translation account for most of the errors committed by the students. Results further showed that the students performed their limited ability in rendering lexical items accurately, constructing syntax, and using English collocations. Sources of translation errors could be traced by both inter-lingual and intra-lingual interference or integration of both sources as there often exists an overlapping between the two sources on the learners.

\subsection{Implications of Pedagogy}

The syllabus designers in both general English subjects and translation subjects should emphasize enhancing the vocabulary of the students particularly the ability to choose English words correctly in contexts and use English collocations as well. It should also focus on the linguistic competence of the students in terms of constructing English sentences. More translation practice should be provided to English linguistic students, focusing on the challenges of the students in translation. The study highly recommends the translation practices pay attention to transfer competence, particularly lexical choice, and linguistic competence with syntax and word collocations.

Students should be encouraged to read more in English. By that way, they can learn how the native speakers use the vocabulary, how they construct the sentence to express their ideas, how words go together. It is expected to work effectively for the improvement of students' translation performances.

Since some translation errors could be traced with the interference of the mother tongue, it would be better for teachers to warn students about these errors in the English teaching and translation teaching. Furthermore, specific exercises can be designed and administered to help students avoid the habit of mother tongue thinking in English and in translation.

\subsection{Recommendations for Future Research}

It is highly recommended that more research in the field of translation in Vietnamese EFL context be conducted to find out errors committed, source of errors and approaches to avoid these errors. The instrument should be varied using regular tests, homework assignments, exercises, or portfolios to investigate the errors.

\section{References}

American Translators Association. (2016). $\quad$ Retrieved from http://www.atanet.org/certification/aboutexams_overview.php

Benhaddou, M. (1991). Translation quality assessment: A situational/textual model for the evaluation of Arabic/English translations. Unpublished $\mathrm{PhD}$ Thesis, University of Salford. Retrieved from http://usir.salford.ac.uk/2082/

Dewi, H. D. (2015). Comparing two translation assessment models: Correlating student revisions and perspectives. Unpublished PhD Thesis, Kent State University, USA.

Dodds, J. M. (1999). Friends, false friends and foes or back to basics in L1 to L2. In G. Anderman \& M. Rogers (Eds.), Word, Text, Translation: Liber amicorum for Peter Newmark (pp. 56-65). Clevedon: Multilingual Matters.

Gass, S., \& Selinker L. (2008). Second language acquisition: An introductory course (2nd ed.). New York, Routledge.

Goff-Kfouri, C. A. (2004). Testing and evaluation in the translation classroom. Translation Journal, 8(3). Retrieved from http://translationjournal.net

Hang, N., \& Hang, T. (2015). Vietnamese-English translation errors made by second year translation-major students: An initial step towards enhancing translation standards. Scientific Journal, Vietnam National University, 31, 22-32.

Hansen, G. (2009). A classification of errors in translation and revision. In H. Lee-Jahnke, P. A. Schmitt, \& M. Forstner (Eds.), Enhancing Translation Quality: Ways, Means, Methods (pp. 313-327). CIUTI-Forum.

Hansen, G. (2010). Translation "Errors". In Y. Gambier \& L. V. Doorslaer (Eds.), Handbook of Translation Studies, 1. Amsterdam: John Benjamins Publishing Company.

Hatim, B., \& Mason, I. (1997). The translator as communicator. Oxon: Routledge.

James, C. (1998). Errors in language learning and use. Boston: Addison Wesley Longman.

Kaweera, C. (2013). Writing error: a review of interlingual and intralingual interference in EFL context. English Language Teaching, 6(7) 9-18. https://doi.org/10.5539/elt.v6n7p9

Lennon, P. (1991). Error: Some problems of definition, identification, and distinction. Applied Linguistics, 12(2), 
180-195. https://doi.org/10.1093/applin/12.2.180

Melis, N. M., \& Albir, A. H. (2001). Assessment in translation studies: Research Needs. META, XLVI(2), 272-287. https://doi.org/10.7202/003624ar

Na Pham. (2005). Errors in the translation of topic-comment structures of Vietnamese into English. A dissertation. The University of Sydney, Australia. Retrieved from http://researchdirect.westernsydney.edu.au

Neubert, A., \& Shreve, G. (1995). Basic issues in translation studies. Kent, OH, Institute for Applied Linguistics.

Newmark, P. (2003). No global communication with translation. In A. Gunilla \& R. Margaret (Eds.), Translation Today: Trends and Perspectives (pp. 55-67), Clevedon, Multilingual Matters.

Nord, C. (1997). Translating as a purposeful activity: functionalist approaches explained. Manchester, UK: St Jerome Publishing.

Popescu, T. (2013). A Corpus-based approach to translation error analysis. A case-study of Romanian EFL $\begin{array}{lllll}\text { learners. Procedia Social and Behavioral } & \text { Sciences, 83, 247. }\end{array}$ https://doi.org/10.1016/j.sbspro.2013.06.048

Pym, A. (1992). Translation error analysis and the interface with language teaching. In C. Dollerup \& A. Loddegaard (Eds.), The Teaching of Translation (pp. 279-288). Amsterdam: John Benjamins. https://doi.org/10.1075/z.56.42pym

Seguinot, C. (1990). Interpreting errors in translation. META, 25(1), 68-73. https://doi.org/10.7202/004078ar

Suskie, L. A. (1996). Questionnaire survey research: What works (2nd ed.). Tallahassee, FL, The Association for Institutional Research.

Waddington, C. (2001). Different Methods of Evaluating Student Translations: The Question of Validity. Translators' Journal, 46(2), 311-325. https://doi.org/10.7202/004583ar

\section{Copyrights}

Copyright for this article is retained by the author(s), with first publication rights granted to the journal.

This is an open-access article distributed under the terms and conditions of the Creative Commons Attribution license (http://creativecommons.org/licenses/by/4.0/). 